\title{
PUFENDORFOVE IDEJE MORALNOG PRIRODNOG PRAVA I NJIHOVA SUVREMENA REZONANCA
}

\author{
UDK: $340 / 22$ \\ Primljeno: 10. VI. 2018. \\ Pregledni znanstveni rad
}

\begin{abstract}
Prirodno pravo kao temelj države, objašnjeno na precizan i znanstveni način, osnova je moralnopolitičkog argumenta Samuela von Pufendorfa, što se smatra njegovim najvećim doprinosom političkom diskursu. Njegovo djelo je nastavak pokušaja da se integrira zakon prirode u pravni sustav, izgradi društvo zasnovano na principima poštovanja i samopoštovanja i znanstveno ospori Aristotelova tvrdnja da ne može biti društvene sigurnosti u samom moralu čovjeka. Kao rodonačelnik ideje moralnog prirodnog prava, Pufendorf je dao nesumnjiv doprinos razvoju pravne znanosti jedinstvenim metodološkim spojem etike, prava, povijesti, teologije i politike. Njegove ideje federalizma, dvojnog suvereniteta, države kao pravne osobe, preventivne penologije, primata svjetovne vlasti i moralnih koncepata pojedinca na kojima se dalje temelje i države i savezi država, nepravedno su zaboravljeni, a mnogi pokušaji da se oživi njegovo djelo ostali su na razini reduciranja ovog izvrsnog znanstvenika na jedan mali djelić njegova rada.
\end{abstract}

Ključne riječi: Pufendorf, moralni koncepti, Sveto Rimsko Carstvo, prirodno pravo, društveni ugovor, savezi država

1. Uvodna napomena; 2. Samuel von Pufendorf - bio-bibliografska nota; 3. Teološko u Pufendorfovu djelu; 4. Moralni koncepti; 5. Obveze moralnih bića; 6. O dužnostima u pogledu vladanja državom; 7. Društveni ugovor; 8. Pufendorfova država; 9. Savezi država; 9. Suvremeno čitanje Pufendorfa: 10. Zaključna napomena.

\section{UVODNA NAPOMENA}

Ideja da država postoji kao entitet u prostoru i vremenu, neovisan o crkvenom pravu, mnogo je starija od perioda prosvijećenog apsolutizma, ali za razvoj ideje države kao cjelovito prikazanog moralnog entiteta i povlačenje analogije između političkih skupina kao grupe i pojedinca sa svojim urođenim pravima bez sumnje je najznačajniji doprinos teoriji prirodnog prava Samuela von Pufendorfa. Upravo je njegova teorija države u svoje vrijeme bila „najutjecajnijom pojedinačnom teorijom države, snažnijeg odjeka od Hobbesove“. ${ }^{1}$ Dok je Hobbes opisao

1 Holland, B.: „Review of The Moral Person of the State: Pufendorf, Sovereignty and Cosmopolite Polities", Political Theory, Cambridge University Press, 2017., str. 221. 
državu kao „umjetnog čovjeka“, kao imitaciju fizičke osobe, Pufendorf je razvio tu ideju opisom države kao personae moralis što je zapravo prakoncept pravne osobe u suvremenom smislu. Ovaj rad pokušava prikazati Pufendorfov doprinos suvremenom pravu, kroz kratak prikaz koncepata koje on razvija ili revolucionira, te njih povezati s konkretnim društvenim uvjetima u kojima nastaju, kako bi se novim osvrtom na stare ideje prema Samuelu von Pufendorfu ispravio barem djelić nepravde znanstvenog zaborava, i kako bi se on iznova čitao u današnjim uvjetima.

Predmetom Pufendorfova zanimanja bivali su moral, društvo, država, politika, povijest i međunarodni odnosi. Svojim učenjem o prirodnom pravu, odnosno shvaćanjem da su čovjeku prirodni zakoni urođeni, Pufendorf je uspio razdvojiti pravo od religije i aristotelovskog tradicionalizma, a nadogradnjom jezuitske koncepcije ideju ljudske slobode dogradio je na učenje Luisa Molinae i Francisca Suareza. ${ }^{2}$ Ono po čemu je Pufendorf bio čuven u svoje vrijeme jest njegova sistematičnost u pristupu pravnoj znanosti, gdje metodološki definira pojmove prava, obveza i zakona. Pufendorf je proučavao principe društvenosti pokušavajući identificirati one najuopćenije, najrasprostranjenije, kao principe udruživanja ljudi, odbacujući teološki i realistički koncept kojim se nije pokušavao dati odgovor na praktična pitanja i intelektualne kontroverze. Po njemu su društvo kao politička zajednica i država kao njegov suvremeni izraz nastali slobodnim udruživanjem pater familiasa kao vođa preddržavnog društva.

Pufendorfski je pristup državama i savezima država individualistički jer je država izraz neotuđivih prava i aspiracija jedinke, ugovorni jer se zasniva na društvenom ugovoru, ali i matematički s uzročno-posljedičnim rezoniranjem, a suštinski bitan jer je originalan i suprotstavljen svojim suvremenicima. Drugi su pokušali identificirati Imperij Svetog Rimskog Carstva s drugim oblicima države, ograničenom monarhijom, demokracijom, aristokracijom, apsolutnom monarhijom, ali je Pufendorf imao hrabrost reći da to nije niti jedan od poznatih oblika države. Naravno, takav stav doživljen je kao napad na ujedinjenost i samokoncepciju carstva. Ispostavit će se da je utjecaj rada De statu Imperii Germanici iznad opisanog njemačkog ustavnog sustava jer zorno opisuje povijesne okolnosti koje vode do federalnog udruživanja, odnose dijelova države, suvereniteta država i položaj vlasti unutar sustava i u međunarodnom pravu. Ideju podijeljenog suvereniteta razvijat će dalje u svojoj polemici s Pufendorfom i Thomasom Hobbesom Gottfried Leibniz, naglašavajući da su „drugi, pišući o našoj državi koristili dosta slobodnu terminologiju videći je monstruoznom, ali ako je to istina, odvažit ću se reći da ista čudovišta održavaju Poljaci, Nizozemci i Englezi, pa čak i Španjolci i Francuzi“.”3

Svojim doprinosom ideji urođenih prava, Pufendorf pomaže etabliranju univerzalnih prava i obveza građanina, a svojom konceptualizaciojom države kao apstraktnog moralnog oblika doprinosi i westphalskom raspletu događaja kada će

2 Ideja dihotomije čovjeka kao zbroja volje i intelekta, usvojena u kasnijim Pufendorfovim djelima, po Hollandeu je bez sumnje umotvorina Louisa Molina, Holland, ibid., str. 33.

3 Leibnitz, G. W.: De Suprematu Principum Germanie, Patrick Riley ed. Cambridge University Press, 2012., str. 118. 
nositelji vlasti konačno prihvatiti obvezu da se i same države podvrgnu vladavini prava, ideji teritorijalnog integriteta država i principu nemiješanja u unutarnje odnose, čime će formalno priznati ideju suverene države. Hedley Bull će u svojoj raspravi o Grotiusovom prirodnom pravu ustvrditi kako je „Westphalski mir označio ne samo nastanak modernih država već i međunarodnog sustava država i međunarodnog prava”. ${ }^{4}$ Nadalje, kako će zamijetiti James Mackintosh: ,Za Pufendorfa su prirodna individualna prava čovjeka izvor javnoga prava kao prava države, javno je pravo samo posudilo svoje principe od privatnog prava".5

\section{SAMUEL VON PUFENDORF - BIO-BIBLIOGRAFSKA NOTA}

Samuel von Pufendorf rođen je 1632. godine u gradiću Dorfchemnitzu u današnjoj njemačkoj pokrajini Saksoniji, tada kvaziautonomnoj njemačkoj državi u okviru Svetog Rimskog Carstva (dalje SRC). Jedan je od najutjecajnijih filozofa morala i prirodnog prava u razdoblju sedamnaestog i osamnaestog stoljeća, kada rađanje moderne nacionalne države nameće potrebu njezine analize. Studirao je protestantsku teologiju, retoriku, logiku, grčku i latinsku filozofiju, bio političar, veleposlanik i univerzitetski profesor. Suvremenik je krupnih političkih promjena politika i granica koje na jednoj strani donose francuska osvajanja na zapadu i otomanska na jugu, tridesetgodišnjeg rata, kao i slabosti složenog sustava saveza država u kojem je živio, kao praktičnog pokušaja država centralne Europe da se savezom spriječi povratak na stanje stalnih unutarnjih ratova između država koje čine SRC i da prema van vodi jedinstvena politika prema državama takmacima. Suvremenik je njemačkog i švicarskog stjecanja državnog suvereniteta Westphalskim mirom 1648. gdje se na štetu Svetog Rimskog Carstva ostvaruje njihovo pravo na superioritas teritorials što inspirira njegove analize interesa država kroz povijesne radove gdje takav rasplet događaja objašnjava kako univerzalnim sadržajem prirodnog prava država tako i njihovom etičkom svrhom. Leonard Krieger će za Pufendorfa napisati da je „mislilac koji je težio iznaći balans između znanja i kontempliranja, praktične aplikacije i akcije, postići ravnotežu uma i srca, analize i intuicije, rezona i vjere uvjeren u ultimativni suverenitet univerzuuma koji nadilazi ljudsku nesavršenost" ${ }^{\text {" }} 6$

Za razliku od nacionalnih država toga doba Engleske, Francuske, Rusije, Švedske i Danske koje nastaju ranije i razvijaju se u okvirima prirodnih čvrsto definiranih nacionalnih granica, Pufendorfova je kritika opis Imperija kao ničije zemlje, jednostavnog zbroja autonomnih teritorija s fragmentiranim poretkom bez jasne supstance, nenacionalna, bez prave državne organizacije vlasti. Ona nije u stanju

4 Bull, H.: The importance of Grotius in the Study of International Relations, Clarendon Press, Oxford, 1990., str. 77.

5 Mackintosh, J.: Discourse in the study of the law of nature and nations, Pratt and Co. Boston, 1843. str 95 .

6 Krieger, L.: Pufendorf - the Politics of discretion, Modern Europe, Chicago University Press, Chicago, 1965. str. 1007. 
voditi međunarodnu politiku bez miješanja svojih susjeda koji čine sve da Sveto Rimsko Carstvo, a Zatim i Njemačko Carstvo niti ne postanu čvršćim državama, jer bi svaka koncentracija vlasti predstavljala prijetnju ravnoteži na kontinentu, pa stoga daju potporu i sklapaju međudržavne aranžmane s njemačkim kneževinama i slobodnim gradovima, slabeći tako svaku mogućnost centralizma.

Usprkos takvoj slabosti države, SRC daje svijetu nemjerljiv doprinos razvoju pravne misli.

Po Josephu Rovanu, prvenstveno krozučenje o prirodnom pravu i prosvjetiteljstvo, SRC ,postaje nova antička Grčka - intelektualno superiorna ali bez čvrste vlasti“.? Pravni sustav i kultura koja se tu razvila bez premca je u ostatku svijeta, a Pufendorf tome daje svoj doprinos.

Svoj rad na prirodnom pravu Pufendorf započinje knjigom Elementorum jurisprudentiae universalis II libri (1660.), nastavlja u De obligatione Patriam 1663., De rebus gestis Philippi Augustae 1663., De statu imperii Germanici 1667., a potpuno razvija u De jure naturae at gentium 1672. godine. Njegovo djelo Specimen controversarium iz 1678., iako pisano pod snažnim utjecajem stoicizma, rimskoga prava, kršćanske skolastike, a osobito Huga Grotiusa, Fernanda Vasquesa, Franciska de Vitorie i Franciska Suareza, smatra se začetkom, a on rodonačelnikom, potpuno novog filozofskog žanra moralne discipline prirodnoga prava.

Pufendorf, pod pseudonimom Severini de Mozambano Veronensis i lažnim identitetom talijanskog putopisca, 1668. objavljuje djelo o nepravilnim državnim oblicima De republica irregulari u okviru dvoknjižja o statusu njemačke države De Statu Imperii Germanici izdavanog između 1667. i 1669., čije će autorstvo nijekati do kraja života jer je ono hereza svog vremena koju on kao sveučilišni profesor međunarodnog prava i filologije sebi ne smije dopustiti. Djelo je optuženo za podsticanje želje da se uništi politički sustav, pisac za manjak ,ustavnog patriotizma", te je djelo proskribirano kao antiintelektualno, nijekajuće glede genetskog i povijesnog razloga državnog postojanja Carstva. ${ }^{8} \mathrm{U}$ obranu neznanog autora Pufendorf će navesti da se radi o patriotskom djelu koje se zalaže za očuvanje sloboda i vjere kao i westphalskih temelja jer nije motivirano samo željom da se izbliza promatra snaga i bogatstvo nacije i njezina raznolikost naroda, kao i sveza koja ih u jednom tako glomaznom tijelu drži zajedno, već upravo željom da se ponude lijekovi za loše stanje. „Kada se nađe bolest, lako je otkriti i pravi lijek, ali savjetovanje pacijenta koji ne prihvaća da je bolestan da uzme neki lijek koji sam ne traži nije mudro i često izaziva njegov gnjev. “9

Pufendorf svoju državu vidi kao bezimeni oblik nastao stjecajem društvenih uvjeta: „Savez je nastao u žurbi bez samopromišljanja članica o budućnosti i stoga se ne može od njeg načiniti regularni oblik države ništa više nego što krojač može

\footnotetext{
Shulze, H.: Foreword, German federalism, Palgrave Macmillan, Hampshire, 2002., str. ix.

8 Siedler, M. J.: Introduction to Present State of Germany, Edmund Bochun ed., Indianapolis, 2007. str. 8 .

9 Pufendorf, S.: The present state of Germany Edmund Bohun trans, Indianapolis Liberty Fund, 2007. http://oll.libertyfund.org/titles/1890 pristup 22. III. 2018., str.90.
} 
napraviti lijep odjevni predmet nakon što je svoje platno isjekao u komadiće i krpice prije nego li je odlučio pravi li mušku ili žensku odjeću“" ${ }^{10}$

Pufendorf razrađuje Grotiusovu ideju prirodnog prava po kojoj je prirodni zakon zasnovan na racionalnoj i socijalnoj prirodi čovječanstva. Prema Pufendorfu, Bog kao vladar kako prirodnih zakona, tako i pozitivnih zakona, ne bi dopustio da ova dva zakona budu u suprotnosti jedan s drugim, dajući značajan doprinos tomu da diskurs prirodnih prava postane lingua franca moralne, političke i društvene misli osamnaestog stoljeća. ${ }^{11}$

U djelu Uvod u povijest temeljnih kraljevstava i država Europe (Introductio ad historiam praecipouruum regnorum et statuum modernorum in Europa), 1683., Pufendorf se iskazuje kao teoretičar međunarodnog javnog prava, povjesničar i ustavni komparativist. To djelo zasnovano je na filozofskoj teoriji država i konkretizacija je stavova iznesenih u De jure naturae et gentium na način da bi oni bez takvog konkretnog konteksta povijesne analize ostali apstraktni.

Pufendorfova je država idealistički koncept i suprotnost državi u kojoj živi bolesti Svetog Rimskog Carstva dijagnosticirao je u De statu imperii Germanici, gdje kaže da država koja ima dvije ili više glava u svojoj osnovi ima reproduciranje konflikata predgrađanskog, preddržavnog društva i prema tomu sama priziva svoj nestanak. Sveto je Rimsko Carstvo neregularna forma države, čija neregularnost slabi samu državu, umjesto da država bude lijekom za ljudsku nesavršenost i slabosti. ${ }^{12}$ Prema tomu, SRC je rudiment države koji ne može pružiti niti sigurnost građanima od težnji njihovih susjeda u danim povijesnim okolnostima. To je miješana monarhija u kojoj je imperator ostao suveren, ali je izvršnu vlast u mnogim ključnim aspektima vlasti obvezan dijeliti s jednim ili više vijeća (Reichstaende).

Od Svetog je Rimskog Carstva za Pufenodorfa ostao samo ostatak ostatka, puko ime. Sveto Njemačko Carstvo samo je odsjaj prošlosti: „Rekavši to, čini mi se da naivno griješe svi koji pomišljaju da je Njemačko Carstvo uspjelo zauzeti mjesto Rimskog Imperija i nastaviti njegovo kraljevstvo, kada je taj imperij s prijestolnicom u Rimu uništen mnogo prije nego što je Njemačko Carstvo nastalo" ${ }^{13}$ Pufendorf, pišući o pravu, filozofiji, povijesti, ne samo da spaja te discipline već konceptualizira potpuno nove društvene odnose čime ostavlja nemjerljiv doprinos političkoj i pravnoj misli prosvjetiteljstva.

10 Pufendorf, S.: The present state of Germany, str. 85.

11 Hakonssen, K., Natural Law and moral philosophy, from Grotius to the scotish enlightment, Cambridge University Press, New York, 1996., str. 63.

12 Pufendorf, S.: The present State of Germany, Edmund Bohun trans, Indianapolis Liberty Fund, 2007., http://oll.libertyfund.org/titles/1890, pristup 22. III. 2018., str.76, 84, 90.

13 Pufendorf, S.: The Present State of Germany, str. 26. 


\section{TEOLOŠKO U PUFENDORFOVU DJELU}

Kao sin luteranskog svećenika i suvremenik snažnog utjecaja kršćanske dogme na sve sfere društvenog života, Pufendorf je značajan dio svojeg rada posvetio odnosu čovjek - Bog. Po njemu Bog ograničava racionalnu volju i slobodu izbora čovjeka, jer Bog je stvorio svijet (entia physica) kao vlastitu kreaciju i ostvarenje svoje volje, stoga je on vrhovni zakonodavac, a čovjek je stvorio moralni svijet (entia moralia) u skladu s onim što je vjerovao da je primjereno Božjoj volji i u skladu s tim čovjek se mora pokoravati općim zakonitostima. ${ }^{14}$

Kako s teološkog aspekta čovjek ne može znati Božju volju, to može samo pokušati izgraditi pravedan sustav u vjeri da postupa prema prirodnim zakonima. S pravne točke gledišta, zakon je dobar ako promovira dobro, omogućujući na taj način identificiranje najboljih normi kao pretpostavljenih pravila Božje volje. Stoga se kao jedino rješenje uspostavi sustava u skladu s voljom Boga nameće stalno preispitivanje čovjekove vlastite prirode koja je u skladu s onim što je potrebno da bi se živio dobar život, prema tome čovjekova primarna briga jest očuvanje mira i blagostanja, a njegove slabosti i nesreća koju nosi rat, koji je u suprotnome izvjestan, tjeraju ga da živi u skladu s prirodnim pravom i voljom Stvoritelja. Da bi mogao poštovati Božju volju i osigurati sebi blagostanje, čovjek se prirodno udružuje s ostalim ljudima, pa je tako suština osnovnog zakona prirode imperativ svakom pojedincu da koliko god može kultivira i održava prema drugima miroljubivu društvenost koja je u skladu s prirodnim karakterom čovjeka i čovječanstva uopće. ${ }^{15}$

Gottfried Wilhelm Leibniz, kao Pufendorfov Erzfeind (turc. Din - dušmanin, hrv. zakleti neprijatelj) s kojim u svojim radovima polemizira do kraja života, optužit će Pufendorfa za biblijski fundamentalizam i nazvati ga sićušnim pravnikom, a još sićušnijim filozofom. ${ }^{16}$

Samo Njemačko Carstvo, kao sastavni dio SRC-a, u Pufendorfovo je doba bilo uređeno po federativnim načelima što upitnom čini nedjeljivu suverenost kao ideju. Teritorijalnim širenjem Rimsko Carstvo nije postalo prava monarhija, niti bilo koji drugi vid političkog sustava koji bi se mogao nazvati državom, već carstvo većeg broja polisa koji zadržavaju svoju suverenost. Zakoni koji su formulirani na razini iznad polisa izvršavaju se isključivo kao običajno-moralna praksa, doduše s povremenom tendencijom jačanja ingerencija autoriteta i vlasti vladara donošenjem narodnih zakona lex populi, osobito u vrijeme principata. Prema tome, u SRC-u nalazimo začetke suvereniteta, nedovršene zbog stalnog sukoba svjetovnog vladara s drugim autoritetom koji nosi papa. To postojanje druge vlasti sacerdotorum imperium gdje postoji vlast koja je u najmanju ruku jednaka carskoj u SRC-u,

14 Pufendorf, Samuel von (2009.), Two Books of the Elements of Universal Jurisprudence. Edited with an introduction by Thomas Behme. Liberty Fund, Indianapolis (Revised edition of the translation by William Abbot Oldfather, Oxford, 1931.), Uvod, str. 10.

15 Pufendorf, Samuel von, Of the Law of Nature and Nations, Eight Books, 4th Edition, Lawbook Exchange London, 2005., str. 769.

16 Doering, D.: The Practice of Reason: Leibniz and his Controversy, John Banjamins Publishing Co. Amsterdam, 2010., str. 250. 
gelazijanska ${ }^{17}$ ce doktrina nazvati paralelizmom vlasti, a danas bismo je nazvali podijeljenim suverenitetom. Takva je vlast, naravno, bila nedjelotvorna, ona je ,agregat bez forme koji je aberacija nastala napuštanjem jedne čiste forme“ ${ }^{18} \mathrm{~S}$ aspekta Crkve, njezina vlast je potpuna i potječe izravno od Boga, obuhvaćajući i svjetovnu, iako u 13. stoljeću Toma Akvinski ponovno otkriva Aristotelovo djelo i načela razuma kojim se omogućuje distinkcija i nadmoć državnog nad crkvenim pravom, odnosno razvitak ideje državnoga suvereniteta kao zemaljskog, sekularnog vida državne vlasti. ${ }^{19}$ Feudalizam sam po sebi znači podijeljenu lojalnost, stoga i ne čudi da je državna forma imitacija vlasničke strukture, prema Pufendorfu, ,papa u vremenu nakon Zlatne bule bez skrupula prisvaja vlast da ekskomunicira kralja i objavi da su njegovi podanici oslobođeni obveza vjernosti prema njemu pa je imperator samo papin vazal, a država feud Svete Stolice“ .20

Jean Bodin je još u 16. stoljeću u Šest knjiga o republici suverenom definirao izvornu vlast koja nije nastala iz druge, neograničenu osim vlastitim zakonima i nedjeljivu tako da ne postoji više vrhovnih vlasti na istom teritoriju. Na osnovama Bodinove republike i Hobbesova društvenog ugovora, Grotius, Vatel, a najzad i Pufendorf, detaljnije će rabiti pojam suvereniteta. Taj je period vrijeme građanskih ratova, dinastičkih borbi, pravne nesigurnosti, rađanja nacionalnih država na krvavim tragovima Bartolomejske noći kao masovnog pokolja protestanata i Augsburškoga mira 1555. godine kao točke u kojoj se Crkva odriče svoje uloge u političkom životu, a narodni jezik i nacionalna svijest prihvaćaju kao temeljna identitetska pitanja i svakog pojedinca i svake države.

Pufendorf smatra da se suverena vlast regularne države ogleda u činjenici da na jednome teritoriju ne može biti više ili konkurentske vlasti od one koja pripada vladaru, te mu sva imovina načelno pripada jer da mu načelno pripada cijeli državni teritorij. Državna vlast je neograničena jer na svojem teritoriju kontrolira ne samo sve ljude već i sve subdržavne kolektive: gospodarske, političke, pa i vjerske zajednice. Svi zakoni moraju biti sukladni prirodnim pravima čovjeka i kolektiviteta i prihvatljivi s moralnog, religijskog, tradicijskog aspekta, ali su oni ipak izraz državnog prava neovisnog o volji Crkve. ${ }^{21}$ Tako vjersku zajednicu i civilno društvo čine iste osobe, isti su im i ciljevi u vidu postizanja pravde, ali vlasti jedna drugu ne normiraju, već su odvojene svaka na svojemu cjelovitom polju na kojem djeluju kao

17 U svojem pismu bizantskom imperatoru papa Gelasius 494. godine definira regalis potestas $\mathrm{i}$ auctoritas sacrata pontificum, što je najslavnije crkveno tumačenje dualizma vlasti jer odvaja duhovnu od zemaljske vlasti pri čemu je sekularna privremena i inferiorna.

18 Krieger, L. The politics of Discretion: Pufendorf and the exception of natural law http://journals. sagepub.com/doi/abs/10.1177/000271626636700182 pristup 28. II. 2018., Krieger, L.: Pufendorf - the politics of discretion, Modern Europe, Chicago University Press, Chicago, 1965., str. 1007.

19 Rehm, H.: Geschichte der Staatsrechtswisenschaftt, Freiburg, 1892., str. 82. Navodi: Istina je da Aristotel priznaje da međudržavni odnosi izrastaju ka federalnom tipu kroz osobito obrambene i carinske saveze, ali njega ta pojava zanima samo utoliko koliko je dokaz da savezi nisu nove države, perfektni samodostatni polisi.

20 Pufendorf, S.: The present state of Germany str. 61.

21 Engleska doktrina o suverenitetu govori kao o realnoj kategoriji i izrazu vlasti, a o vladavini prava - rule of law - kao o metajuridičkoj. 
societates perfectae s odvojenim pravnim sustavima i svim sredstvima potrebnim za njihovo provođenje u djelo. Država bi time bila pravi vlasnik crkvene imovine, ali bi uredila njezino korištenje u vjerske svrhe, to je Pufendorfovo viđenje svjetovne države koja se ne miješa u rad vjerskih zajednica, pa ni u njihova građanska stanja, ali ta autonomija Crkve predstavlja vid delegiranog državnog suvereniteta. Takav sekularizam podrazumijeva da je i Crkva neki vid pravne osobe, vidljiva organizacijska forma društva i društvenih sloboda. ${ }^{22} \mathrm{U}$ vremenu Pufendorfa ovakvo direktno oponiranje katoličkoj doktrini o Crkvi kao obliku neovisnom o državi, pravo je svetogrđe. Nezaobilazan dio Pufendorfova djela je stoga teološki kontekst luteranske kršćanske kulture kao socijalni i intelektualni kontekst u kojem kroz etički voluntarizam i svoje moralne entitete razvija takve temeljne norme, koncepte, klasifikacije i diskurse, koherentno i pragmatično začinje sekularni koncept države prosvjetiteljstva.

Osnovni element svake moralne radnje za Pufendorfa predstavlja razlog zašto se nešto čini slobodnom voljom, uslijed čega se svaki fizički pokret smatra proizvodom odluke i slobodne volje. ${ }^{23}$ Pufendorfov formalni element slobodne volje jest pripisivanje posljedica koje slobodnom voljom mogu biti nametnute onome tko nešto čini. ${ }^{24}$ Iz takvog shvaćanja proizlazi da onaj koji čini predstavlja moralni uzrok, pa se njemu pripisuje i ono dobro i loše što slijedi - moralna kauza kao posljedica njegove aktivnosti, čime implicira da svaki pojedinac odgovara za svoje odluke.

\section{MORALNI KONCEPTI}

U prvom dijelu dvoknjižja Elementorum jurisprudentiae universalis, Pufendorf daje svoje definicije moralnih i pravnih koncepata, koje on naziva moralnim entitetima entia moralia, što su ljudima nametnuti kao prirodni zakoni na osnovi kojih se vrijednosno promatra i analizira svaka pravna norma, kao i pravni sustav u cijelosti, njihovim stavljanjem nasuprot fizičkim entitetima entia physica. Moralni entiteti, prema Pufendorfu, imaju važnu ulogu jer pomažu pri utvrđivanju društvenih pojava kao loših ili dobrih, odnosno pravednih ili nepravednih, pa on tako pravi distinkciju između njih i kategorizira ih na: state/status, moral persons, moral qualities, moral quantity. ${ }^{25}$

Položaj ili status čine uvjeti ili okvir u kojem osoba zapravo radi i postoji. Oni mogu biti prirodni, koji su nametnuti Božjom voljom, ili sporedni položaji, odnosno status, koji je nametnut u skladu s ljudskom voljom da bi se čovjek pokoravao

22 Hanquist, D.: Pufendorf redivivus: Stat-kyrka-relationen I ett katolskt perspektiv, http://journals. lub.lu.se/index.php/st/article/view/2171 pristup 1. II. 2018.

23 Ibid.

24 U tekstu se koristi pojam agent $\mathrm{u}$ smislu svjesne osobe koja djeluje.

25 Pufendorf, S.: Two Books of the Elements of Universal Jurisprudence. Edited with an introduction by Thomas Behme. Liberty Fund, Indianapolis (Revised edition of the translation by William Abbot Oldfather 1931.), Oxford, 2009., Uvod, str. 10-11. 
osnovnim prirodnim zakonima, a samim tim i očuvao svoju društvenost kroz ustanove braka, društvenog statusa i općenito političkog društva. Status moralne osobe značajka je koja se odnosi i na grupe, a ne samo na pojedince. Razdvajajući koncept moralne osobe od jedinke kao racionalnog bića, Pufendorf ukazuje na to da pojedinac može imati nekoliko moralnih osoba, svaka sa svojim dužnostima u ovisnosti o svojoj društvenoj svrsi.

Moralne kvalitete utječu na moralnu razinu svake osobe. Pufendorf razlikuje formalne moralne kvalitete (npr. čast) i operativne moralne kvalitete koji mogu biti podijeljeni na pasivne, odnosno one koje omogućavaju nekome da zakonito djeluje ili pretrpi nešto, prizna ili primi, te aktivne kvalitete pomoću kojih možemo utjecati na druge, koji čine tkivo društvenog života, kao što su moć (potestas), obveza (obligatio) i pravo (ius). Pufendorfova moralna kvaniteta odnosi se na vrednovanje ljudi, stvari ili njihovih djela u smislu društvenog statusa ili prestiža, njihove ekonomske vrijednosti, zasluga, društvenih kazni ili nagrada.

Polazeći od definicije slobodne volje, koju predstavljaju radnje uvjetovane voljom čovjeka a ne prirodnim stanjem, Pufendorf pravi podjelu između materijalnih, osnovnih i formalnih elemenata volje. Svaki čovjek na određeno ili neodređeno vrijeme ima neki položaj u društvu, determiniran prirodom ili slučajnošću. Prirodan, s obzirom na to da nema posebno određenje, on naziva ljudskim životom, te kao takav uključuje obvezu pokoravanjima prirodnim zakonima, kako prema sebi, tako i prema drugim ljudima, što znači živjeti u okvirima društvenih međuodnosa, uvažavanjem drugih ljudi i time stjecanjem određenih privilegija i prava među ljudima. Kao suprotnost prirodnom položaju javlja se brutalnost, kojom ne vladaju međusobna prava, već se ljudi jedni prema drugima odnose kako mogu i žele, pa čak i uz nasilje. ${ }^{26}$

\section{OBVEZE MORALNIH BIĆA}

Baveći se obvezama poslušnosti koju svi imamo kao moralna bića, Pufendorf je stvorio teoriju prirodnih obveza koje uključuju:

dužnost prema Bogu (adversus Deum),

dužnost prema samome sebi (adversus seipsum),

dužnost prema drugim ljudima (adversus alios homines).

Jedna od primarnih dužnosti čovjeka jest dužnost prema Bogu koji nas je stvorio da živimo jedni s drugima i uredio prirodne zakone koji su za to neophodni. Ove dužnosti dijele se na teorijske i praktične. Teorijske dužnosti ogledaju se u tome da moramo spoznati Boga kao onog tko nam je podario život i njegovu pravu prirodu, dok praktične dužnosti znače da Boga moramo slaviti i moliti mu se. ${ }^{27}$ Odvajajući

26 Ibid., str. 27.

27 Pufendorf, S.: Of the Law of Nature and Nations, Eight Books, 4th Edition, London, 1729., Knjiga 1, Poglavlje 4., str. 34. 
prirodno pravo od Božjeg zakona, Pufendorf smatra da se Božjim dužostima mora baviti teologija, a obvezama prema sebi i drugima moral, praveći dalje distinkciju između prirodnog prava i pozitivnog prava. Prirodno pravo postoji prije države u svom nužnom i nepromjenjivom obliku, kojemu se pozitivno pravo mora pokoravati.

Kada govori o dužnostima prema samome sebi, on ih svrstava u dvije kategorije: dužnosti prema umu i dužnosti prema tijelu. Pufendorf dužnosti prema umu stavlja u funkciju usavršavanja i učenja, što znači da bismo bili korisni članovi zajednice, moramo izabrati i obavljati zanimanje koje je u skladu s našim sposobnostima i prilikama u zajednici, a s obzirom na to da tijelo predstavlja instrument uma, obveza nam je brinuti se o njemu kako bismo mogli obavljati svoje poslove na najbolji način. ${ }^{28}$

Dužnosti prema ostalim ljudima dijeli na: apsolutne, odnosno bezuvjetne i kondicionalne, uvjetne. Najbitnija bezuvjetna dužnost prema drugim ljudima sastoji se u tome da se nikome ne smije nanositi šteta, jer je to temeljno pravilo na kojem počiva svako društvo, prema tome, ova dužnost je najviša i najznačajnija od svih. Ukoliko ipak dođe do toga da nekome nanesemo štetu, naša je moralna dužnost nadoknaditi je u cijelosti. Druga važna bezuvjetna dužnost prema drugim ljudima jest tretirati ih jednako kao i same sebe jer i drugi ljudi imaju dignitet $\mathrm{i}$ samopoštovanje kao i mi sami, pa ne smijemo nikoga tretirati kao manje vrijednoga.

Osim dužnosti koje moralna osoba ima, Pufendorf pravi i analogiju između jedinke i kolektiviteta. Kada se govori o moralnoj osobi, misli se na osobu koja ima građanska prava odnosno osobnu slobodu ili na javne osobe kao nositelje javnog statusa koje ostaju u domeni privatnoga. ${ }^{29}$ Distinkcija među privatnim osobama vrši se prema spolu, klasi, zanimanju, građanskoj pripadnosti. Žena se ne uvažava u društvu kao muškarac, njezini stavovi ne vrednuju se tako visoko, kao ni njene uvrede, pa ženama nije ni dopušteno baviti se javnim poslovima. ${ }^{30}$ Pored ove podjele, tu je i razlika zasnovana na moralnom statusu u odnosu na godine što znači da se ne tretiraju na isti način stari i mladi, njihov autoritet nije jednak pa neke stvari nisu dozvoljene mladoj osobi, kao što ni položaj stranaca nije jednak položaju građana. ${ }^{31}$

Što se obveza koje nameće zakon tiče, Pufendorf je vjerovao da one moraju ispunjavati dva uvjeta: moraju biti racionalno uvjerljive i djelotvorne, a zakon je uvjerljiv ukoliko promovira dobro jer na taj način se čovjek, kao racionalno biće, može uvjeriti u to da mu se podvrgne, odnosno pokori. ${ }^{32}$ A dobro i loše moguće je razlikovati na način da se priroda dobroga sagledava u onoj sposobnosti koju neka norma ima da sačuva, pomogne ili dopuni prirodna prava. Sto se događa, međutim, kada osoba ne preza ni od koga? Kada nema tog straha koji će je spriječiti da čini loše ili da izbjegava svoje dužnosti? Pufendorf označava Boga kao silu koja nas obvezuje u ispunjavanju dužnosti, zbog straha od njega kao vrhovnog zakonodavca

\footnotetext{
28 Ibid., str. 153.

29 Pufendorf, S.: Ibid., str. 39.

30 Ibid., str. 39.

31 Ibid., str. 38.

32 Ibid., Pufendorf, S.: str. 123-126.
} 
i krajnjeg izvršitelja zakona. Iako je Božja kazna spora, ona ipak na kraju svakoga stigne, pa tako svi oni koji trpe patnje (a nisu ateisti) na kraju se ipak okreću njemu u nadi za spasenjem, a ukoliko se ukloni Bog kao krajnji izvor straha, među ljudima neće postojati poslušnost niti će vladati mir. ${ }^{33}$ Svaki je čovjek obvezan biti u miru s ostalim ljudima, a mir se može uspostaviti samo kroz međusobno poštovanje ljudi, pridržavajući se obveza prirodnog prava uzdržavanjem od nanošenja bola i štete drugima, te ukoliko i dođe do povreda, one se moraju riješiti sporazumno ili ih rješava sudac.

Kada se ne poštuju zakoni prirode i kada se sigurnost čovjeka može osigurati jedino uporabom sile, tada dolazi do rata. Iako se rat može sprovoditi s vremena na vrijeme, kada je on jedino rješenje za očuvanje sigurnosti i trajnog mira, dakle iako Pufendorf prihvaća ideju pravednog rata, ipak se po njemu rat ne može smatrati prirodnom, čovjeku predodređenom metodom očuvanja prava. Baš kao i Grotius i njegovo shvaćanje o pravednim i nepravednim odnosno o dopuštenim i nedopuštenim ratovima, gdje kao opravdanje za pravedni rat navodi pretrpljene nepravde, nužnu obranu, povrat otetog teritorija, kažnjavanje druge države za prekršaj prirodnog ili božanskog zakona, dozvoljen je rat kao sredstvo da se postigne mir, odnosno da se ograniči zlo. Za Pufendorfa, poput mira, i rat može biti univerzalan ili pojedinačan. Univerzalan rat Pufendorf opisuje kao ponašanje divljih zvijeri kada nitko ne postupa u skladu s pravima drugih, već se rukovodi isključivo silom, zanemarujući sami temelj prirodnih prava.

\section{O DUŽNOSTIMA U POGLEDU VLADANJA DRŽAVOM}

Vladanje državom zahtijeva prije svega posvećenost i razumijevanje onoga što se radi, jer vladar mora biti svjestan dužnosti i uopće poslova koji su mu namijenjeni, mora biti svjestan svoje društvene svrhe, mora se odreći zadovoljstava i zabava koje bi preusmjeravale njegovu pozornost $\mathrm{s}$ tako bitne funkcije.

Vladar mora za svoje suradnike birati one ljude koji imaju iskustva i najbolje vještine u vođenju državnih poslova. Opće je dobro vrhovni zakon svih, jer se prije svega mora osigurati zajednička dobrobit, pa tako narod treba biti mjerilom uspješnosti vladavine. Pravedni zakoni moraju biti tako striktni u osmišljavanju kazni da spriječe ljude da ih prekrše, moraju biti jasni i moraju biti promovirajući za dobrobit države i njezinih članova. ${ }^{34}$

Pufendorf navodi da samo postojanje zakona nije dovoljno ukoliko ne postoji njihovo izvršenje, pa tako svaka osoba mora osjetiti posljedice nepodvrgavanja zakonu. ${ }^{35}$ Ministri pored vladara obavljaju poslove u rukovođenju državom, ali iako im vladar dodjeljuje dužosti, ipak je sva moć u njegovim rukama. U ovisnosti o kvaliteti tih ministara, i posao će biti izvršen dobro ili loše, stoga ih vladar mora

\footnotetext{
33 Pufendorf, S.: str. 129-130.

34 Ibid., str. 216.

35 Ibid., str. 217.
} 
nagrađivati ili kažnjavati, kao primjer ostalima. Pa tako, kada su zločesti ljudi ohrabreni da se upuste u koruptivna djela, dužnost je vladara da ih spriječi u tome i da ih kazni. ${ }^{36}$

Za Pufendorfa, država se temelji na posebnim zakonima, a to su građanski zakoni koji proizlaze iz prirodnog zakona. Pored toga što nas postojanje zakona primorava na poštovanje nekih pravila, građanski zakoni imaju pravo nad životom i smrću bilo indirektno, kada su naši životi izloženi u obrani naroda, ili direktno kada se radi o ubojstvu kao državnoj kazni za neki zločin. Država ima moć oduzeti život subjektu direktno putem smrtne kazne onda kada se radi o nekom gnjusnom zločinu. Kako kažnjavanje ima za cilj uspostavljanje stabilnosti i mira među ljudima, Pufendorf je i preteča preventivnog penološkog sustava u kaznenom pravu jer navodi da bi trebalo promatrati korist države od svake kazne, kakve će ona posljedice imati po ponašanje podanika, i nikako se zakonodavac ne bi smio rukovoditi uživanjem pri nanošenju boli osobi koja se kažnjava jer to je neljudski, već krajnji cilj kazne mora biti opće dobro svih ljudi koje je moguće postići prevencijom od ponavljanja grešaka, tako da onaj tko je jednom učinio takvo zlodjelo nakon kazne više neće ni razmišljati o istom, a pored toga će i ostalima služiti kao primjer. $^{37}$

\section{DRUŠTVENI UGOVOR}

Pufendorfova teorija o društvenom ugovoru oslanja se na Grotiusovo shvaćanje da je društveni ugovor u skladu s čovjekovom prirodnom društvenošću i uzajamnim priznavanjem i zaštitom njegovih moralnih prava. Obveza poštovanja ovih prava nije prema njemu posljedica života u zajednici, već obveza sadržana u prirodnim zakonima naše racionalnosti i društvenosti. Ljudi su, prema Pufendorfu, nesposobni živjeti sami, a da bi mogli živjeti u miru, neophodno je postojanje nekog zakona, odnosno obveza koje će ih primorati na pokoravanje općim normama.

Pufendorfovo shaćanje zakona poslužilo je i samome J. J. Rousseauu kao prototip teorije društvenog ugovora kao modela građanskog udruživanja jer narod podčinjen zakonima zapravo je i njihov tvorac, s obzirom na to da samo oni koji se udružuju imaju pravo određivati uvjete koji će vladati u tom društvu. Budući da je za Pufendorfa udruživanje ljudi u političku zajednicu nužnost, on je razvio ideju o nastanku društva odnosno da od ujedinjenja pojedinačnih osoba nastaje složena osoba što znači da grupa pojedinaca formira zajednicu i nakon tog ujedinjenja smatra se da zajednica, država ili društvo posjeduje opću volju i da je u joj sadržana volja jedinki koje je čine, te se činjenje države ima smatrati djelima i voljom jedne osobe, a ne njih nekoliko. Kada se pojedinci udružuju i svoju volju podvrgavaju volji jedne osobe, spremni su odluke te vodeće osobe priznati kao svoje pa je tako jedan predstavnik kolektiva. Tako udruženi obrazuju zajednicu, pa se želja svih tih pojedinačnih članova promatra kao želja jedne osobe, a pripisuje

36 Ibid., str. 218.

37 Ibid., str. 225-227. 
cijeloj zajednici. Na taj način donose se i odluke i stječu prava za cijelo društvo. ${ }^{38}$ Država i nije ništa drugo nego moralni entitet koji su ljudi sami sebi nametnuli, sukladno prirodnom pravu, i na taj način nadišli ranije tipove asocijacija koji su se pokazali nefunkcionalnima i time ona proizlazi iz nesigurnosti, povrede prirodnih prava, opasnosti od drugih i samo je odgovor na društvene okolnosti. Prema tomu, Pufendorf, za razliku od Aristotela, ne smatra državu ni idealnim ni prirodnim stadijem u razvoju čovječanstva koji bi spontano nastao iz želje ljudi da žive skupa. Nastanak države posljedica je straha, ljudske izopačenosti, samobitnosti i htijenja da se drugom nanese zlo, Pufendorfova država nije teološka niti antropološka kategorija već realistička, empirijska i povijesna posljedica ljudskih strahova. Kroz socijalnu integraciju jedinke društva se moraliziraju polako artikulirajući i svoju normativnu sferu, donoseći zakone kojima uređuju obveze i prava, samointerpretirajući prirodna prava koja im je podario Tvorac na način kako ih to društvo u tom momentu razumije. Forme društvene suradnje moraju se neprestano održavati i usavršavati, čime dolazi do podvođenja i međunarodnog prava pod prirodnopravne norme. ${ }^{39}$

\section{PUFENDORFOVA DRŽAVA}

Pufendorf je kritičar slabe države, on govori o onome što će poslije opisati Michel Foucault: „Kraj Rimskoga Carstva mora se datirati točno na 1648. godinu kada postaje jasno da Carstvo ne predstavlja vrhovnu vlast i svoje države, da nije više u stanju ostvariti nadu i san da će se jednoga dana objediniti. ... Ono je tijekom godina, desetljeća, možda i stoljeća, postalo praznom školjkom, puževom kućicom bez stanovnika, bez moći integracije, povijesne i političke fascinacije i održivosti pri čemu su oba izraza njegove univerzalnosti Crkva i Država izgubile svoj smisao i svrhu... ${ }^{40}$ Njegova država, tome nasuprot, moralni je entitet $s$ jedinstvenom moralnom osobnošću, dužnošću i svrhom, nju čini intelekt $u$ vidu suverena, koji izražava njezinu volju i intelekt, odlučujući predstavljen kroz zasebna kolektivna vijeća kao konstitucionalističku značajku države i izraz dviju odvojenih volja. U njemačkoj državi vlast ima monarh, ali intelekt je u vijeću svake njezine državne jedinice čime Pufendorf upravo gradi temelje ideje „fakultativnog suvereniteta“ $i$ omogućava razdvajanje suverena od države koja postoji neovisno i bez parazitiranja na bilo kojem vijeću ili pojedincu.

Strukturu vlasti Njemačkog Carstva čine države koje imaju pravo glasa u stalnoj imperijalnoj Dieti (Dieta Imperii, njem. Reichstag, kao konfederalni parlament teritorijalnih jedinica) koju čine tri različite institucije: elektorsko vijeće, vijeće kneževa (prinčeva) i vijeće slobodnih gradova. Vijeće elektora bira među plemićima imperatora kojega potvrđuje rimski papa s obzirom na to da titulu dobiva od Svete Stolice. Imperator ima pravo predlagati Dieti teme za raspravu. Tri vijeća

38 Ibid., str. 42

39 Ibid., str. 62

40 Foucault, M.: Sicherheit, Territorium, Bevoelkerung, Gechichte der Gouvernmentalitaet I, Shurkamp Taschenbuch Wissenschaft, Frankfurt a. Main, 2004., str. 421. 
zasjedaju odvojeno da bi nakon završenih rasprava usuglasila zajedničke odluke conclusum imperii i prezentirala ih imperatoru radi njegove ratifikacije čime bi to postale i odluke kralja. U vijećima je pravo glasa nejednako pa predstavnik jednog teritorija može imati jedan ili više glasova ili pravo glasovati u više vijeća. „Veliki broj različitih odluka u kojima države imaju različita prava glasa čini ih manje zadovoljnim no što bi u dobro ujedinjenom savezu država trebale biti." ${ }^{41}$ U praksi u Dieti su ambasadori konfederalnih jedinica koje s vremenom dobivaju sve više državne samostalnosti u odnosu na ovo tijelo i na centralnu vlast. Ustavni sustav zasniva se na drevnom njemačkom običajnom pravu i više povelja Diete od kojih su najznačajnije Lex Saxonum iz 803., kodifikacija Rimsko pravo iz 1130. i Zlatna bula iz 1356. godine. Pravni sustav zasniva se na mješavini kanonskog, građanskog prava i starih germanskih običaja, zakona opće primjene donesenih od Diete i partikularnih zakona federalnih jedinica. Sve do Westphalskoga mira odluke Diete imale su status zakona i bile primjenjive na čitavom teritoriju kraljevstva. Westphalski mir 1648. okončava samu ideju imperija, a Dieta postaje konsultativno tijelo u stalnom zasjedanju - Immerwaehrender Reichstag. Odluke se više ne mogu donositi ni većinom glasova, a uvodi se i institut suodlučivanja protestantskih i katoličkih zemalja.

Bez obzira na to što je u 16. i 17. stoljeću najčešće prikazano kao ,propala država, od koje su preživjele samo one kneževine koje su uspjele izgraditi kompaktne i velike teritorije i moćne institucije", ${ }^{42}$ neupitno je da je Carstvo opstajalo, ne na jasnim institucionalnim rješenjima i političkim okvirima, već kao imperij svojih pravnih normi, a da su stalni sukobi oko prirode i izvora vlasti doprinijeli razvitku kolektivnih procesa odlučivanja i rješavanja konflikata, pa i temeljnoj verziji sustava provjera i kontrola. Charles Louis Montesquieu opisuje Carstvo kao labavu konfederaciju bez prave kompozitnosti, dok Helmut Neuhaus odbacuje i ideju da je riječ o federaciji kao i onu da se radi o konfederaciji. Iako po njemu SRC nije ni Bundesstaat niti Staatenbund, on ima federalne elemente. ${ }^{43}$

Za Pufendorfa kralj nije suveren jer u Imperiju ne može postupati bez pristanka Imperijalne Diete, nema pravo smjene ili razrješenja plemića, nema pravo na ubiranje poreza, nema legislativna prava, ne odlučuje o ratu i miru, ne odlučuje o teritorijalnim savezima niti o religijskim pitanjima ${ }^{44} \mathrm{Na}$ isti način i Dieti je za djelovanje potrebna njegova suglasnost pa su pristuni zastoji, što je Pufendorfu dovoljno za zaključak da se ne radi o ograničenoj monarhiji. To nije ni miješani oblik republike jer vrhovna vlast nije ni u rukama izabrane nekolicine, zapravo je rastočena u više različitih osoba i vijeća. Ta vijeća nisu ni stalna pa država nema ni pravog vladara, ni vladu, niti stalni parlament, jer Dieta ne predstavlja građane već države i gradove, nije demokratsko, političko, pa ni stalno tijelo. Ugovor država i

${ }^{41}$ Pufendorf, S.: The Present State of Germany, str. 85.

42 Wilson, P. H: „Still a monstruosity? Some reflections on early modern German statehood“", The Historical Journal, Vol 49. No 2. Cambridge University Press Cambridge, 2006., str. 568.

43 Neuhaus, H.: The federal principle of the Holy Roman Empire, Stuttgart, 1998., str. 35-48.

44 Pufendorf, S.: The present state of Germany, str. 53-55. 
imperatora sastoji se u tomu da će mu biti lojalni i poslušni dok njihovo bogatstvo i silu upotrebljava u svrhu javnog dobra, pa se one stavljaju u isti rang s njim, stoga to je primarno ugovorni odnos. Imperator je više sluga nego gospodar, a njegove titule zadržane su iz pukog sažaljenja. ${ }^{45}$

Pokušaji da se suvremenim pojmovima države i prava opiše SRC zbog njegove složene višestupanjske strukture zastaju već na pitanjima je li to bila država. Ukoliko i jest, kojeg je ta država bila tipa? Kako Peter Wilson navodi, ta ideja da je Imperij morao biti nešto, neki već poznati državni oblik, ima svoj korijen u Aristotelovoj filozofiji gdje su tipološkim kriterijima fenomeni po definiciji jasno razgraničeni jedni od drugih. ${ }^{46}$

Starija njemačka teorija podijeljeni je suverenitet smatrala mogućim, dok će klasična njemačka teorija države definirati suverenu vlast kao KompetenzKompetenz- nadležnost da odlučuje o nadležnosti, o onome što će urediti ustavom i zakonima a što neće, nepodijeljeni bodinovski shvaćen suverenitet. Za razliku od Bodina, Pufendorf ne misli da je imperijalna Dieta kao skupština država nositelj suvereniteta, a time ne predstavlja ni ograničenje monarhijskog oblika države.

Svaki federalizam koji proistječe iz ovako nejednakih jedinica, asimetričnih rješenja i koegzistencije različitog vjerskog i svjetovnoga konteksta, morao je biti teško shvatljiv i kompliciran jer je operativno nejednakost jedinica nosila nejednako pravo glasa i zastupanja, asimetriju koja onemogućava integrativni potencijal, a snaži autonomiju jedinica jer ne može razviti garante opstanka centralne razine. Volja i privrženost većeg broja ljudi najefikasnije može biti ujedinjena kada je svatko od njih spreman svoju volju podvrći volji određenog čovjeka kao vladara ili vijeću ljudi, pa će se u tom slučaju, kada se odlučuje o određenim pitanjima koja će rješavati zastupničko tijelo, volja vijeća uvažavati kao volja pojedinačne osobe. Ujedinjeni voljom i moći, pojedinac obvezuje da će svoju političku moć prenijeti na vijeće kao reprezenta, a isto tako izvršavati njegova naređenja, pa oni postaju inkorporirani u jednu zajednicu, vijeće ima suverenitet predstavljanja volje zajednice, odluke vijeća smatraju se voljom svih koje zastupa. ${ }^{47}$

Pufendorf kritički navodi nedostatke svih poznatih oblika vladavine koje nalazi u lošoj upravljačkoj strukturi kao i u individualnoj prirodi onih koji vrše vlast, pa je nedostatak vladavine jednoga situacija kada monarh nema dobre vještine vođenja države i zanemaruje dobrobit zajednice postajući okrutan, drzak, nepravedan ili se rasipa sredstvima koja su namijenjena zajednici, a nedostatak aristokracije nejednakost i nepravednost do koje bi došlo ako se u vijeću nađu nedorasli svojim zadaćama ili oni koji bi javna sredstva dodjeljivali sami sebi. Demokracija prema Pufendorfu sa sobom nosi mogućnost da se neprijatne i konfliktne osobe sa žarom

45 Idem., str. 23-53.

46 Wilson, P. H.: „Still a monstruosity? Some reflections on early modern German statehood“, The Historical Journal, Vol 49. No 2., Cambridge University Press Cambridge, 2006., str. 566.

47 Pufendorf, Samuel von, 1673/2003 The Whole Duty of Man According to the Law of Nature, trans. A. Tooke, ed. I. Hunter, D. Saunders, Liberty Fund., 2007., http://oll.libertyfund.org/titles/1890 pristup 1. II. 2018., str. 194. 
i tvrdoglavo drže svojih neispravnih ideja i mišljenja ili da se talentirani ljudi čije su ideje korisne društvu drže po strani i odbačeni, a oni bezvrijedni biraju u vladu. ${ }^{48}$

Slijedeći učenje većine teoretičara prosvijećenog apsolutizma, Pufendorf favorizira apsolutističke i centralizirane državne oblike s jasnom strukturom vlasti, retorički sugerirajući da su SRC i Njemačko Carstvo korumpirani, demodirani, farsični oblici države. Malobrojnu opoziciju takvom njegovu mišljenju kao općem mjestu vladajućeg prosvijećenog apsolutizma iznose kao kritiku odvjetnik Johan Stephan Pueter i pisac Justus Moeser koje će njihovi suvremenici prokazati kao konzervativce. Promičući tako ideju političkog centrizma Pufendorf srazmjerno zanemaruje drugi stup oko kojega će se kasnije ujediniti Njemačka država federalizam kao oslonac stupa pravne države (Rechtsstatlichkeit). Osnovna kritika Pufendorfa jest u tomu što ne primjećuje tihu revoluciju političkog diskursa čiji najbitniji element predstavlja pojava federalne svijesti na tlu Europe izgrađena prvenstveno djelovanjem Wetzlarskoga kraljevskog suda koji je upravo utemeljitelj liberalne filozofije pravne države. Pufendorf nije bio u stanju sublimirati ono što će izraziti Karl von Rotteck: „Država je asocijacija, Verein, ona obuhvaća sve ljudske težnje jedne određene nacije u jednom određenom stadiju društveno-povijesnog razvoja". ${ }^{49}$

Iako je svjedočio razornoj devastaciji tridesetgodišnjeg rata, Pufendorf dužnosti ljudi sukladne prirodnom moralnom pravu vidi kao ljubaznost, mirotvorstvo i zajedničku obvezu kultivacije društvenosti i promidžbe mira. ${ }^{50}$ Pufendorf nije teoretičar rata svih protiv sviju, njegovo prirodno ljudsko stanje nije ratno. Principijelno odbacivanje ostvarivanja političkih ciljeva ratom rezultat je njegova nezadovoljstvom ishodom Westphalskoga mira i ostvarenim pravom pojedinih kneževina njemačkog carstva da istupaju kao nositelji državnog suvereniteta. U kasnijim radovima još više naglašava aktivnu ulogu individue u promicanju društvenih vrijednosti, a države kao najsnažnijeg moralnog entiteta i moralne osobe koja svoj legalitet crpi iz društvenog suglasja. Stoga djelovanjem političkih osoba državu treba ojačati kao jasan koncept i izraz vrhovnog suvereniteta metodama moralnosti i mira.

Pufendorf je i zakonski minimalist: on smatra da građanskim zakonima nema potrebe regulirati više područja života nego što je nužno tražiti od građanina da poštuje kako bi bio dobar podanik. ${ }^{51}$ Kako Tacitus veli: „Corruptissima re publica plurimae leges - najviše zakona ima u najpokvarenijoj državi“",52 a Pufendorfova norma želi kreirati pravedno i dobro društvo.

48 Ibid., str. 204-205.

49 Umbach, M.: History and Federalism in Nation-State Formation, German federalism, Past, Present, Future, Palgrave Macmilan Hampshire, 2002., str. 52.

50 Pufendorf, S.: Natural state of men, str. 9.

51 Pufendorf, S.: DJN VII, 9.5., str. 242.

52 Tacitus, K.: Anali, Sabrana djela Kornelija Tacita, Matica hrvatska - biblioteka Grčki i rimski klasici, Zagreb, 2006., str. 117. 


\section{SAVEZI DRŽAVA}

Po Pufendorfovoj definiciji, lige naroda ili savezi država mirovni su ugovori međunarodnog prava ograničeni vremenski kao interesne skupine i uslijed toga privremeni, te ograničeni brojem članica. Suverenitet ne treba dijeliti jer to dovodi do urušavanja, to fragmentira i potkopava efektivnost državne vlasti zbog čega trpe legislativne, sudske, gospodarske, ratne i sve druge funkcije u državi, a za saveze to donosi međunarodnu anarhiju. Ukoliko nema donošenja odluka bez suglasnosti pluraliziranih tijela od kojih svako treba pristati na određeno uređenje, oni će se zajedno držati dok postoji potreba, a nedostatak jake sveze rezultira raspadom saveza već na rješavanju pojedinih pitanja.

Takav limit konfederacije kao sustavni nedostatak nije trenutačan, jer nesumnjivo SRC je postojao i ne može se svesti samo na mirovni sporazum članica, on je izgradio složene mehanizme i odnose, dug period u vremenu vršio nesumnjivo državne zadaće i politike. Dapače, kroz 16. stoljeće došlo je do tihe evolucije njegovih institucija, političkih, kulturnih i građanskih vrednota čijim su se proučavanjem u dvadesetom stoljeću bavili Peter Moraw i Volker Press. SRC i Njemačko carstvo nesumnjivo su opstajali kao (kon)federacije s razmjerno izgrađenim sustavima i institucijama na nekoj vrsti prednacionalnog ili nenacionalnog federalnoga koncepta. U svakom slučaju nisu predstavljali ruinirane kaotične tvorevine, kako ih opisuje prusko-germanska povijesna škola, već su bili sustavi koji su u određenom vremenu ispunajavali svoju svrhu i prilično efektivno vršili mirovnu i obrambenu ulogu (Verteidigungs und Friedensordnung) u čitavoj središnjoj Europi, osiguravajući ne samo prava nositelja državne vlasti već i prava građana protiv svojih vladara. Ti višerezinski sustavi izgradili su neovisan najviši sud Reichskmmergericht u Wetzlaru i Reichshofgericht u Beču. Ukoliko su i Reichstag i kneževska vijeća, i Landstaende (kao komunualno- teritorijalno-personalni pokreti - vijeća) bili dio jedinstvenog ustavnog mehanizma uspostave kolektivne volje i ostvarenja prirodnih prava, onda je Carstvo neovisno o tome je li monarhija, federacija država ili feudalna hijerarhija predstavljalo dobar razvojni oblik političke kulture i alternativni pravac razvitka države na nacionalnim kriterijima. Dapače, različiti državni oblici nisu međusobno isključivi čak ni u istom vremenu i na jednom prostoru.

Država ne može biti „propala” jer ne postoji idealan oblik niti država kao konstrukt bez vremena i sadržaja, ona jest samo povijesni moment razvitka, sredstvo ostvarenja prirodnih prava. I sam Pufendorf kaže da je ,pitanje potječe li vlast iz prirode ili ustanove upravo neumjesno jer je jasno da su je ljudi nametnuli drugima. Privatno pravo je tek uzurpirano zajedničko." ${ }^{{ }^{3} 3} \mathrm{~Pa}$ ipak on nije zagovornik evolucije, naročito ne razvitka federalnih struktura. Za njega je rješenje u iznalasku ličnosti monarha koji će izgraditi državni duh i predstavljati Staatsbildende Kraefte države, najbolje rješenje za trajan i održiv mir.

Proučavanjem različitih državnih oblika i političkih sustava, Pufendorf daje svoj doprinos razvitku suvremenog ustavno-političkog komparativizma, ustvrdivši

53 Pufendorf, DJN IV., iv. 1. 
pritom da nisu svi oblici uređenja pogodni za svaku državu jer neki zahtijevaju određene ljudske dispozicije građana, pa nema univerzalnih oblika, već oni ovise o povijesnim okolnostima i ponuđenim alternativama. Ipak, Pufendorf ne idealizira državu već priznaje da je kao plod ljudi nesavršenih po prirodi i ona sama nesavršen kostrukt. Taj nedostatak ne može se razriješiti niti mješovitim oblicima države gdje bi se od poznatih oblika države uzele pojedine odlike i kreirao hibridni sustav, već bi to umjesto do neovisne države dovelo do kreacije koja bi bila monstruozne prirode.

U svojoj Republici Platon je ponudio homološki prikaz države koja po njemu ima svoj razum koji predstavljaju njezini filozofi, svoj duh koji čine njezini ratnici i tek koji simboliziraju njezini radnici, te ako bilo koji od ovih konstituirajućih elemenata države prevlada u individualnom ili političkom životu, stradaju pravda i vrlina. I Pufendorf koristi homologiju uspoređujući Sveto Rimsko Carstvo s deformiranim čovjekom, skoro čudovištem, te analitički opservira tendencije ljudskoga ponašanja nalazeći da su jedinke slabe, tjeskobne, ljubomorne, praznovjerne, lijene, odbojne, često perverzne, da se ne slažu u mišljenju s drugima a često niti sa samim sobom, te da nisu u stanju živjeti bez pomoći i u zajednici s drugim osobama pa su stoga malobrojne dobro uređene države. Upravo Pufendorfova usporedba SRC-a s kreacijom sličnom čudovištu, il monstro simile u djelu De statu imperii Germanici, najkontroverznija je postavka u njemu koja je izazvala najviše različitih tumačenja. SRC je za Pufendorfa umjetna tvorevina zbog množine nositelja državne vlasti, a sposobnost umjetnih tvorevina ovisi o harmoniji njihovih dijelova i o vezama i savezima.

Neregularan oblik vlasti predstavljaju i unije koje su suprotne samoj suštini vladavine i u kojima može biti množina kao mješavina svih naprijed navedenih sustavnih nedostataka. Te neregularne vladavine loše su organizirane države, gdje nije moguće zakonodavnu i izvršnu vlast povjeriti jedinstvenom tijelu. Primjerice Njemačko Carstvo služi kao povijesni prototip neregularnog oblika države gdje je vladavina podijeljena između imperatora, glasača, skupštine, teritorijalnih vladara. Takvi mješoviti oblici države mogu proizvesti samo nakaznost, pa se ni Njemačko Carstvo ni Sveto Rimsko Carstvo ne mogu smatrati državama jer se ne uklapaju u formu države, jer ne postoji unutar tih sustava nositelj suverene vlasti. ${ }^{54}$ Pufendorf smatra da u jednoj državi mora postojati vrhovna i apsolutna moć, jedan autoritet koji ima isključivo pravo prema kojemu se zajednica upravlja i koji je uvek superioran, nedodirljiv jer ne postoji drugi autoritet iznad njega koji bi njega mogao kazniti ili preispitivati njegov način vladavine. Pufendorf ističe da prema takvom državnom autoritetu mora postojati u državi poštovanje u primanju i izvršavanju naređenja, pa i u podnošenju okrutnosti vladajućega analogan žestini koja se podnosi u odnosima roditelja i djece. ${ }^{55}$

54 Pufendorf, S.: The Present State of Germany, trans. by Edmund Bohun, 1969., Liberty Fund, 2007., str. 173-176.

55 Pufendorf, Samuel von, 1673/2003 The Whole Duty of Man According to the Law of Nature, trans. A. Tooke, ed. I. Hunter, D. Saunders, Liberty Fund., str. 209. 
Martin Wight smatra da je Pufendorf kovač termina savez država, saveza što ga čini nekoliko država koje su se povezale da bi stvorile zajedničko tijelo, a zadržale su vlastiti suverenitet, te da su na ovom konceptu kasnije razvijane konfederalne ideje kao preteča internacionalnog globalnog poretka. ${ }^{56} \mathrm{U}$ opisu Njemačkog Carstva Pufendorf naglašava da taj iregularni sustav suverenih država djeluje kao degenerativan korumpirani oblik koji se teško može vratiti u normalno obličje, ${ }^{57}$ ne može se obraniti od vanjskih neprijatelja (prvenstveno Francuske) jer je ,ustav bolesno sastavljen okvir vlasti“". ${ }^{58}$

Pufendorf opisuje principe federalizma kao saveza država koje mogu tvoriti države povezane trajnim sporazumom, uobičajeno iz želje da zadrže svoju samostalnost, pri tome nemajući same dovoljnu moć da se obrane protiv zajedničkih neprijatelja, ugovarajući da će se vrhovni suverenitet vršiti samo uz pristanak svih. ${ }^{59}$ To je zajednica koju mogu jednostrano napustiti, a u regularnom su savezu članice podjednake snage. U donošenju odluka nema preglasavanja, suverenitet je zadržan na osnovama međunarodnog prava, građani jedinica su ravnopravni, a dvije osnovne ustavne odredbe (njemački Urklausen) jesu pružanje pomoći i mehanizam odlučivanja o sporovima. U federaciji svaka od članica ima obvezu pomoći drugoj u slučaju ugroženosti. Ta obligacija proizlazi iz dvostranog ugovora i svrhe, obveze lojalnosti savezu, zakletve o zajedništvu Bundestreue. Druga Urklause je postojanje arbitražnog mehanizma koji će razriješiti sukobe partnera u savezu, a time i garantirati zabranu rata, teritorijalnu nepovredivost i neovisnost svakoj od njih. ${ }^{60}$

Pufendorf prepoznaje mogućnost da u jednoj zajednici nastane ustavna praznina uslijed nedostatka vladara, interregnum, i ovaj je period nesavršeno stanje države gdje se ljudi drže u skupini temeljem prvobitnog društvenog ugovora, a prije svega zbog svoje zajedničke ljubavi prema svojoj zemlji i radi očuvanja nje i njihove budućnosti, gdje se svi trude da obnove vladu što prije, a da bi se spriječile štete i povreda prirodnih prava. ${ }^{61}$

\section{SUVREMENO ČITANJE PUFENDORFA}

Kada je Pufendorf Sveto Rimsko Carstvo opisao kao nepravilno tijelo nalik mitskoj životinji chimeri, on je naznačio njegovu osobinu pripadanja različitim nespojivim vrstama, dakle ono je neprirodno, bezglavo - acephalous, ono je greška prirode koja usprkos tomu nastavlja svoj život. Pojedine Pufendorfove postavke kao

56 Wight, M.: Systems of states, Leicester University Press, Leicester, 1977., str. 21-40.

57 Pufendorf, S.: The present state of Germany, str. 76.

58 Ibid., str. 84.

59 Schuetze, R.: Political Philosophy of Federalism, In Max Planck Encyclopedia of Comparative Constitutional Law Cambridge, 2016., str 4.

60 Beaud, O.: The founding Constitution Reflections on the Constitution a Federation and its Peculiarity http://juspoliticum.com/article/The-Founding-Constitution-Reflections-on-the-Constitutionof-a-Federation-and-its-Peculiarity-1149.html, pristup 2. III. 2018.

${ }_{61}$ Pufendorf, S.: DJN, str. 210. 
što su pravna osobnost države, društveni ugovor, moral i prirodna prava kao temelj sustava, odvojenost države od Crkve ili preventivni razlozi kazne u penološkom sustavu danas su općeprihvaćeni i nama samorazumljivi do mjere da je njegova uloga u formuliranju teza o ovim društvenim odnosima potpuno zaboravljena, čak iako je dao crtice važne za suvremenu političku i pravnu misao. Pojedine njegove postavke pokazale su se netočnima, ali su ipak ostavile važno svjedočanstvo vremena, pružajući temelj daljoj znanstvenoj debati. No ono po čemu će se ponovno pobuditi interes znanstvene javnosti za Pufendorfa njegov je opis nepravilnih bezimenih oblika države.

Današnje globalizirano društvo pruža nam mnoštvo primjera neregularnih oblika države, saveza i formi bez jasne podjele vlasti sa složenim državnim strukturama i kompliciranim odnosima. Međunarodno i unutarnje ustavno pravo prepleteni su bez jasnih granica čime je suverenitet $u$ nacionalnom smislu relativiziran, a država iz čvrste strukture postaje adaptivni oblik, djelo u nastajanju. Primjerice, kanadski federalizam, razvijen na američkom konceptu podjele vlasti, ali s pragmatskim rješenjima složene društvene stvarnosti duboko različitih saveznih jedinica iz kolonijalnih, etničkih, lingvističkih, vjerskih, institucionalnih razloga, kao i uslijed složenih odnosa britanske krune s provincijama, iregularan je državni oblik. Odlikuje ga nestatičan, stalno promjenjiv odnos u kojem federalne sveze evoluiraju čas ka centralizaciji, čas ka ligi neovisnih država, pa i dezintegraciji. „,Kanadu često nazivaju mozaikom, a ja preferiram sliku tapiserije s mnogo niti i boja i lijepih vješto složenih oblika, pa ako prođemo iza tapiserije, vidjet ćemo i mnoštvo kompliciranih čvorova." ${ }^{2}$ Položaj kanadskih provincija formira se u pregovaračkom postupku kontinuiranih konzultacija i pregovora vrlo slično imperijalnoj Dieti Svetog Rimskog Carstva.

No za komparaciju iregularnih oblika države ne moramo tragati za udaljenim državama jer atipične forme državnosti posvuda su oko nas. Možemo ih naći u Bosni i Hercegovini kao kompromisnoj državi, ili u Europskoj uniji kao kvazidržavnom sustavu. Pravna priroda tih oblika kontroverzna je, složena i neobjašnjiva pojmom nedjeljivog državnog suvereniteta, a federalizam koji se u njima razvija spoj je ili srednji put, mješovita struktura između nacionalne i međunarodne organizacije.

Jedinice koje participiraju kao sudionici u Bosni i Hercegovini i u Europskoj uniji imaju autonomiju ali ne i suverenitet, jer postoji djelokrug u kojem se moraju podrediti isključivoj vlasti centralne razine, njezinim institucijama. Institucije centralne razine relativno su malobrojne zbog čega koristi institucije članica kao svoje, dok provedbu ali i dio kreacije sustava preuzima sudska vlast. Nedostaje jasno strukturirana izvršna vlast, uključujući i vladu kao organ s jasnim kompetencijama. Ustav se sastoji od više dokumenata izričito međunarodnopravnog karaktera, usvojenih od strane različitih aktera u različito vrijeme zbog čega je konstitucionalizacija proces, planiran, usmjeren is dalekosežnim ciljevima. Ustavni su sustavi sedimentirani, komplicirani, institucionalno kompleksni i više izraz povijesnih razloga nego stvarne potrebe. Zajednički identitet i ideologija prisutni su

62 Trudeau, P.: The essential Trudeau, McClelland \& Stewart, Toronto, 1998., str. 177. 
samo na nižoj razini, a pripadanje zajednici lišeno je ustavnog patriotizma. Izborni sustavi su kompromitirani, glas manjih slabije čujan. Kao i Sveto Rimsko Carstvo (SRC), tako EU i BiH imaju po dva vrhovna suda. Sudovi EU-a u Luxembourgu i Sud ljudskih prava u Strasbourgu ne samo da imaju različite nadležnosti, već pripadaju i različitim institucijama - jedan Uniji, drugi Vijeću Europe.

Pa iako i BiH i EU trpe različite kritike i svakodnevne izazove, to ne dovodi do smrti organizma. Postoje brojni pokušaji da se Sveto Rimsko Carstvo prikaže kao medievalni uzor Europske unije, da se od pravne tradicije stvori moderni mit, što naravno predstavlja rizik od distorzije prošlosti. Bez obzira na važno intelektualno nasljeđe, usporedbe su, po Joachimu Whaleyu, ${ }^{63}$ neesencijalne, bez obzira na tendenciju odlučivanja na supranacionalnom i sudbenom polju i demistificiranje suvereniteta države, to je nostalgični san o vrsti federacije koja drži skupa svoje različite dijelove razdvojene na regionalnim principima u najvećoj mogućoj mjeri. ${ }^{64}$ Hoće li takav vid novog federalizma ovoga puta uspjeti u evoluciji, ostaje da se vidi. Svaka idealizacija ranijih poredaka, pa i onog koji se ne zasniva na ideji nacionalne države, vid je novog nacionalizma. Obnovljeni interes za SRC svakako je pokušaj da EU nađe izvor svoje ideologije, povijesne, političke i pravne kulture. Europska unija kao ideja omogućila je sagledavanje nenacionalnoga koncepta država u mnogo ljepšem svjetlu nego prije.

Suvremena komparacija EU - SRC postala je uobičajena, a time i ideja da Carstvo može poslužiti kao uzor Uniji. Heinz Schilling je pisao o republikanskom doprinosu tradicije njemačkih slobodnih gradova, Michael Stolleis o osebujnom ustavu SRC-a, Peter Claus Hartmann o SRC-u kao uzoru suvremene Europske unije očitovane u jakim regionalnim strukturama i slabom centru, Karl Otmar o potpunom prekidu njemačke povijesti koji se desio oko 1806., Reinhart Koselleck opisuje prvi Reich kao i predmoderno i postmoderno nacionalno i postnacionalno društvo. Georg Schmidt sugerira da SRC u biti nije toliko različit od monolitnih kompozitnih monarhija svog doba kakve su Francuska, Španjolska i Britanija. Iako je imao mnogo slabiju centralnu vlast, njegove komponente teritorijalne jedinice vršile su klasične državne funkcije. Bez obzira na svoju autonomiju, ostale su u ustavnom zatvorenom sustavu koji je garantirao individualna prava, regulirao sukobe vlasti, omogućavao sprovedbu odluka, osiguravao unutarnji mir i zaštitu od vanjske agresije. Iako u sustavu postoji kompozicija partikularnih država, one su sve i dalje podređene zajedničkoj višoj vlasti. SRC predstavlja „komplementarnu državu“ u kojoj se različite državne funkcije obavljaju na različitim razinama: Reich je nadležan za obranu i pravni sustav, vijeća za implementiranje odluka i upravljanje infrastrukturom, lokalna razina za prava i obveze građana. Georg Schmidt ističe da je već u 16. stoljeću germanska ideja slobode garantirane imperijalnim sudbenim sustavom obuhvaćala i pravo građana da se žale protiv svih odluka nositelja javne vlasti, a od 1648. i slobodu vjerskog opredjeljenja. Kako Schmidt naglašava, ,već

63 Whaley, J.: ,Federal Habits: the Holy Roman Empire and the continuity of German Federalism“, in: Maiken. Umbach (ed.) German Federalism: Past, Present and Future, Houndmills, 2002., str. 24.

64 Umbach, M.: „German federalism in historical perspective“, German Federalism: Past, Present, Future, Palgrave Macmillan, Hampshire, 2002., str. 4-15. 
Pufendorf u prvi plan ističe neotuđiva ljudska prava kompatibilno suvremenoj ideji građanskih prava, prava unutar i prema državi sukladna etičkim i društvenim dužnostima". ${ }^{65}$ Kakav god model ustavnog uređenja da je bilo Carstvo, ono je razvilo ustavni sustav zasnovan na ,pravima i pravdi, federalnom balansu između malih i velikih članica i strogo defanzivnu uporabu vojne sile“".66

Arend Lijphart najpoznatiji je po svom osporavanju Pufendorfove, kasnije teze Roberta Dahla, da je demokracija moguća samo u malim homogenim zajednicama, temeljem koje je na konkretnom primjeru svoje države, Nizozemske, dokazivao da i heterogena, pluralna društva mogu imati demokratski stabilnu vlast i prosperitetnu zemlju. Suprotno Pufendorfu, zaključio je kako konsocijativni ustavni aranžmani mogu biti visoko efektivni u promidžbi stabilnosti, javnih usluga, blagostanja građana i drugog. ${ }^{67}$ Uvjeti za dobre pluralne aranžmane su: snažna organizacija građana u političke partije koje su prinuđene temeljem društvenog ugovora tvoriti koalicije, parlamentarni sustav s proporcionalnom zastupljenošću i društveni konsenzus o osnovama sustava. Ipak, konsocijacije su društveni ugovori i kao takve imaju svoj limit, jer će formalna ustavna struktura funkcionirati samo u uvjetima društvene suglasnosti. Lijphartov konsocionalizam zamišljen je kao srednjovjekovni sustav više stupova društvene moći gdje različiti nositelji društvene moći - crkveni velikodostojnici, vojskovođe, krupni trgovci i zemljoposjednici - imaju utjecaj na javne politike zastupajući svaki svoju društvenu skupinu.

Usložnjavanje javnih funkcija, jačanje drugih klasa kao nositelja vlasti čak je i od modernih unitarnih sustava napravilo sustave decentralizacije do mjere da je razgraničenje $s$ federalnima katkada teško jer lokalne i regionalne jedinice imaju vlastite konstitutivne subsustave, čak i vlastite izvore financiranja. Suvremeni su unitarni sustavi također dinamičke prirode koju će Loughlin definirati kao „pendulum efekt” gdje centralna vlast u momentima društvenog blagostanja sužava svoju ulogu u korist nižih jedinica, a širi svoju ulogu u vremenu krize. ${ }^{68}$

Dana 1. siječnja 2010., Europska je unija, po Osianderu, i službeno postala novim Svetim Rimskim Carstvom jer je uvela vlastitu diplomatsku službu, i u nju imenovala svoje dužnosnike, svoj ustav već ima od 2009. godine, iako se ne radi o demokratskom, formalnom ustavu, a sprema se uvesti i svoju vojsku. Time EU postaje sve manje unija i sve manje europska, s tendencijom pretvaranja u buvljak

65 Schmidt, G.: Geschichte des Alten Reiches. Staat und Nation in der Fruehen Neuzeit 1495-1806, C. H. Beck Verlag Munich, 1999., str. 389-496.

66 Schilling, H.: Reichs-Staat und fruehneuzeitliche Nation der Deutschen oder teilmodernisiertes Reichssystem. Ueberlegungen zu Charakter und Aktualitaet des Alten Reiches, Historische Zeitschrift No 1, Vol 272, 2001., str. 379, https://doi.org/10.1524/hzhz.2001.272.jg.377 pristup 1. III. 2018.

67 Lijphart, A.: The Politics of Accomodation: Pluralism and the Democracy in the Netherlands, University of California Press, 1968., Los Angeles, str. 213.

68 Loughlin, J.: Subnational Government: The French Experience, The Oxford Handbook of Local and Regional Democracy in Europe, Oxford, 2011., str. 159. 
preklapajućih ugovora i nadležnosti, tijelo koje se ne može podvrgnuti nikakvoj

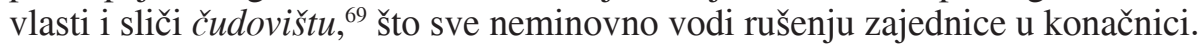

Nije neuobičajeno korištenje metafora u prikazu različitih ustavnih sustava, ali u našem ustavnom pravu nije često korištenje klasičnih poredbenih referenci. Ali ukoliko nas konstitucionalizacija $\mathrm{BiH}$ i Unije nije još dovela do bilo kakve superdržave, mada jest došlo do dramatične transformacije i kreacije ustavnog sustava, ne mora značiti da se radi o nekakvom deformitetu. Ako jedan ustavni sustav ne možemo s lakoćom prepoznati kroz uobičajene značajke drugih suvremenih ustavnih sustava, jednostavno nas tjera da usporedbu vežemo uz nešto iz prošlosti. $\mathrm{BiH}$ i EU postoje tako kratko da je provizorno svako njihovo analiziranje na sadašnjem stupnju razvitka, za razliku od SRC-a koje je opstalo stoljećima.

Za Pufendorfa je državni sustav ljudskoga lika s glavom i udovima, snagom i bolestima. Ako bismo, usprkos svemu, htjeli olako karakterizirati neki sustav kao deformiran, tada se moramo prisjetiti teškoća koje su Bodin i mislioci 16. i 17. stoljeća imali da uopće nađu zajedničke značajke kojima bi opisali postojeći suverenitet, dali tipologiju države, pripisali nužne funkcije i organe ustavnosti.

Samom činjenicom da jedna pojava ne sliči na drugu ne odriče joj se mogućnost superiornosti i prestiža, samom činjenicom da vlast EU-a i BiH nije naročito efikasna ni pravedna, moramo se suočiti s time da je to odvijek bio samo nedostižni ideal.

Zahvaljujući tome, u svima se javlja demokratski deficit kao nedostatak suglasja o tome što su te zajednice i kamo idu. Svi su ovi politički sustavi suprotnost nacionalnim državama, države su smetnja na putu njihova nastanka i one društvene procese guraju u drugom smjeru - prema postnacionalnom.

\section{ZAKLJUČNA NAPOMENA}

Pufendorfov moralistički pristup modernom prirodnom pravu koji je sadržavao neke elemente aristotelovske tradicije i sistematičan znanstveni, gotovo matematički pristup, imao je značajan utjecaj na pravnu misao diljem Europe, kao i na američkom kontinentu, a njegova inovativnost ogleda se u tome što je objedinio etiku i pravo u vlastiti sintetički deduktivni sustav. Dao je značajan doprinos ideji da se definira demokracija kao oblik vladavine u državi. Njegovi koncepti saveza država, neotuđivih prava, fakultativnog suvereniteta, države kao pravne osobe, fundamentalan su doprinos političkoj i pravnoj teoriji. Ako nacionalne države ni danas nisu izgubile gotovo ništa od svojega koncepta i ideje političkoga organiziranja, postnacionalne države fundamentalan su doprinos suvremenim odnosima ,pa ni kraj SRC-a nije bio slijepa ulica". ${ }^{70}$

Za Pufendorfa je Imperij bio kategorija izvan državnog prava, svijet u kojem se miješaju unutarnje s međunarodnim normama, narušavanje teorije društvenog

69 Osiander, A.: Irregulare aliquod corpus et monstro simile - Can historical comparison help understand European Union, Humboldt Universitet papers, Berlin, 2010., str. 2-3.

70 Whaley, ibid., str. 23. 
ugovora kao zatvorenog sustava, prvenstveno stoga što članice saveza sklapaju odnose ili vode ratove ne samo s unutarnjim entitetima, već i s drugim državama čime u savez unose međunarodne odnose. To za njega nije bilo prihvatljivo jer je suverenitet ograničen državom, a svako drugo rješenje ne omogućuje vladaru da upravlja sustavom, ali je Pufendorf u tomu prepoznao bolest, prepoznao nepoznanicu, ponudio lijekove (makar u vidu državnog prosvijećenog apsolutizma), izazvavši time opće zaziranje znanstvene javnosti.

Baš kao i kod Pufendorfa, dužnost je znanstvenika podsjećati konstantno na izvorište države u ljudskim pravima i slobodama urođenima čovjeku jer se u njima krije odgovor na sustavne probleme, čime se omogućava postizanje zdravog odnosa dijelova države, dakle njihova harmonija, čija je suprotnost monstruoznost i bolest.

Koncept suverenih država, kao dominantna paradigma nakon Westphalskog mira koja svijet zamišlja kao skup suverenih entiteta u kojima se odvijaju neovisne političke egzistencije, ozbiljno je doveden u pitanje globalizacijom još od razvoja ljudskih prava koji je uslijedio nakon Drugog svjetskog rata čime je i suverenitet države morao biti podređen prirodnim pravima i direktnoj građanskoj legitimaciji sustava jer su države prestale biti „,crnim kutijama čija neovisnost nalaže zabranu gledanja drugima da ne vide što se dešava unutar njihovih granica". ${ }^{71}$

\section{Literatura:}

Beaud, Olivier: The founding Constitution Reflections on the Constitution a Federation and its Peculiarity http://juspoliticum.com/article/The-Founding-Constitution-Reflectionson-the-Constitution-of-a-Federation-and-its-Peculiarity-1149.html.

Bull, Hedley: The importance of Grotius in the Study of International Relations, Clarendon Press Oxford, 1990.

Cyr, Hugo: Treaty Power of Federated States and International Law, http://juspoliticum. com/article/Treaty-Powers-of-Federated-States-and-International-Law-1117.html.

Doering, Detlef: The Practice of Reason: Leibniz and his Controversy, John Banjamins Publishing Co. Amsterdam, 2010.

Foucault, Michel: Sicherheit, Territorium, Bevoelkerung, Gechichte der Gouvernmentalitaet I, Shurkamp Taschenbuch Wissenschaft, Frankfurt a. Main, 2004.

Hakonssen, Knud, Natural Law and moral philosophy, from Grotius to the scotish enlightment, Cambridge University Press, New York, 1996.

Hanquist, Dan: Pufendorf redivivus: Stat-kyrka- relationen I ett katolskt perspektiv, http://journals.lub.lu.se/index.php/st/article/view/2171.

Holland, Ben: Review of The Moral Person of the State: Pufendorf, Sovereignty and Cosmopolite Polities, Political Theory, Cambridge University Press, 2017.

71 Cyr, H.: Treaty Power of Federated States and International Law http://juspoliticum.com/article/ Treaty-Powers-of-Federated-States-and-International-Law-1117.html, pristup 10. II. 2018. 
Mr. sc. Dragan Šmit: Pufendorfove ideje moralnog prirodnog prava i njihova suvremena rezonanca Zbornik radova Pravnog fakulteta u Splitu, god. 55, 4/2018., str. 893.- 918.

Krieger, Leonard: Pufendorf - the Politics of discretion, Modern Europe, Chicago University Press, Chicago, 1965.

Leibnitz, Gottfried Wilhelm: De Suprematu Principum Germanie, Patrick Riley ed. Cambridge University Press, 2012.

Lijphart, Arend: The Politics of Accomodation: Pluralism and the Democracy in the Netherlands, University of California Press, 1968.

Loughlin, John: Subnational Government: The French Experience, The Oxford Handbook of Local and Regional Democracy in Europe, Oxford, 2011.

Mackintosh, James: Discourse in the study of the law of nature and nations, Pratt and Co., Boston, 1843.

Neuhaus, Helmut: The federal principle of the Holy Roman Empire, Stuttgart, 1998.

Osiander, Andreas: Irregulare aliquod corpus et monstro simile - Can historical comparison help understand European Union, Humboldt Universitet papers, Berlin, 2010.

Pufendorf, Samuel von: Of the Law of Nature and Nations, Eight Books, 4th Edition, Lawbook Exchange, London, 2005.

Pufendorf, Samuel von (2009.), Two Books of the Elements of Universal Jurisprudence. Edited with an introduction by Thomas Behme. Liberty Fund, Indianapolis (Revised edition of the translation by William Abbot Oldfather), Oxford, 1931.

Pufendorf, Samuel: The present state of Germany Edmund Bohun trans, Indianapolis Liberty Fund 2007. http://oll.libertyfund.org/titles/1890.

Pufendorf, Samuel: Of the Law of Nature and Nations, Eight Books, 4th Edition, London, 1729.

Pufendorf, Samuel von, 1673/2003 The Whole Duty of Man According to the Law of Nature, trans. A. Tooke, ed. I. Hunter, D. Saunders, Liberty Fund2007. http://oll.libertyfund. org/titles/1890.

Rehm, Hermann: Geschichte der Staatsrechtswisenschaftt, Freiburg, 1892.

Schilling, Heinz: Reichs-Staat und fruehneuzeitliche Nation der Deutschen oder teilmodernisiertes Reichssystem. Ueberlegungen zu Charakter und Aktualitaet des Alten Reiches, Historische Zeitschrift, No 1, Vol 272, 2001.

Schmidt, Georg: Geschichte des Alten Reiches. Staat und Nation in der Fruehen Neuzeit 1495-1806, C. H. Beck Verlag, Munich, 1999.

Shulze, Hagen: Foreword, German federalism, Palgrave Macmillan, Hampshire, 2002.

Siedler, Michael J.: Introduction to Present State of Germany - Edmund Bochun ed. Indianapolis, 2007.

Tacitus, Kornelije: Anali, Sabrana djela Kornelija Tacita, Matica hrvatska - biblioteka Grčki i rimski klasici, Zagreb, 2006.

Trudeau, Pierre: The essential Trudeau McClelland \& Stewart, Toronto, 1998. 
Umbach, Maiken: „History and Federalism in Nation-State Formation“, German federalism, Past, Present, Future, Palgrave Macmilan, Hampshire, 2002.

Whaley, Joachim: „Federal Habits: the Holy Roman Empire and the continuity of German Federalism“, in: Maiken. Umbach (ed.) German Federalism: Past, Present and Future, Houndmills, 2002.

Wight, Martin: Systems of states, Leicester University Press, Leicester, 1977.

Wilson, Peter H.: „Still a monstruosity? Some reflections on early modern German statehood“, The Historical Journal, Vol 49., No 2., Cambridge University Press Cambridge, 2006.

\section{PUFENDORF'S IDEA OF MORAL NATURAL LAW AND ITS CONTEMPORARY REVERBERATIONS}

Natural law as a foundation of a state, explained in a precise and scientific way, is the basis of the moral and political argument of Samuel von Pufendorf, which is considered to be his greatest contribution to political discourse. His work is the continuation of efforts to integrate the law of nature into the legal system, to build a society based the principles of respect and self-respect and scientifically opposes Aristotel's claim that there cannot be social safety in the very moral of man. As the founder of the idea of moral natural law, Pufendorf has made an undoubtable contribution to the development of legal sciences by a singular, methodological mix of ethics, law, history, theology and politics. His ideas of federalism, dual sovereignty, state as a legal entity, preventive penology, a primate of secular powers and moral concepts of individuals on which states and federation of states is further founded on have unjustly been forgotten. Many attempts to revitalize his work have remained at the level of reducing this excellent scientist to a small little part of his work

Key words: Pufendorf, moral concepcts, Holy Roman Empire, natural law, social contract, state unions 